\title{
КОНЦЕПТ “ДУША” В АРЕАЛЬНІЙ ФРАЗЕОЛОГІЇ
}

\author{
ЗОРЯНА МАЦЮК \\ Східноєвропейський національний університет імені Лесі Українки, Луцьк - Україна \\ Zoriana_Matsiuk@ukr.net; ORCID: 0000-0001-7915-742X
}

\section{МАРІЯ ФЕНКО}

Східноєвропейський національний університет імені Лесі Українки, Луцьк - Україна maria_fenko@ukr.net; ORCID: 0000-0003-2000-2348

\section{KONCEPT „DUSZA” W AREALNEJ FRAZEOLOGII}

\author{
ZORIANA MACIUK \\ Wschodnioeuropejski Uniwersytet Narodowy imienia Łesi Ukrainki, Luck — Ukraina \\ MARIJA FENKO \\ Wschodnioeuropejski Uniwersytet Narodowy imienia Łesi Ukrainki, Łuck — Ukraina
}

STRESZCZENIE. Jedną z najbardziej charakterystycznych cech współczesnej lingwistyki jest geneza i intensywny rozwój nowych obszarów językowych. Do szczególnie aktualnych kwestii należą te, które obejmują badanie konceptów. Artykuł poświęcony jest zagadnieniu refleksji w języku konceptosfery narodu i jej głównych konceptów. To warunkuje potrzebę dalszych badań nad szczegółami strukturyzacji konceptów reprezentowanych przez jednostki frazeologiczne oraz ustalenia ich wzajemnego oddziaływania. Ujawniono potencjał tworzenia treści konceptu „dusza” podczas frazeologizacji jednostek, zidentyfikowano stosunek mentalny do konceptu, zarówno w kulturze materialnej, jak i duchowej. Koncept „dusza” określa znaczną ilość informacji kulturowych i jest podstawą duchowego kodu kultury. We współczesnych koncepcjach lingwistycznokulturowych człowiek postrzegany jest jednocześnie jako nosiciel języka i kultury. Właśnie dlatego znaki językowe mają zdolność pełnienia funkcji znaków kultury, służąc jako środek przedstawienia podstawowych jej zasad. To potwierdza zdolność języka do reprezentowania kulturowej i narodowej tożsamości jego nosicieli.

Słowa kluczowe: frazeologizmy, językowy obraz świata, koncept, areał, mowa dialektalna, symbol, stan psychoemocjonalny 


\title{
KONCEPT “SOUL” IN LOCAL PHRASEOLOGICAL UNITS
}

\author{
ZORIANA MATSIUK \\ Lesya Ukrainka Eastern European National University, Lutsk — Ukraine \\ MARIIA FENKO \\ Lesya Ukrainka Eastern European National University, Lutsk — Ukraine
}

\begin{abstract}
ABSRACT. One of the most striking features of modern linguistics is the emergence and intensive development of new linguistic areas, among which the most relevant ones are those that involve the study of concepts. The article outlines the problem of reflection in the language of the conceptual sphere of the people and its main concepts; the need for further study of the peculiarities of structuring concepts represented by phraseological units, and the establishment of their interaction with each other. The meaning-making potential of the concept "soul" in the phraseologization of structures has been outlined, mental and spiritual attitude have been revealed. Concept "soul" specifies a considerable amount of cultural information and is the basis of the spiritual code of culture. In modern linguocultural concepts, a person is studied as a native speaker of a language and a culture-bearer at the same time. That's why linguistic signs acquire the capability to perform the function of cultural signs, serving as a source of presentation of the main cultural guidelines, which explains the capability of the language to reflect national culture mentality of its speakers.
\end{abstract}

Key words: phraseologisms, linguistic picture of the world, concept, area, dialectal speech, symbol, psychoemotional state

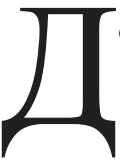

омінантним вектором розвитку сучасної лінгвістики є синергетичне поєднання кількох напрямів - i щодо окремих мовних одиниць, і щодо термінологічних понять. Вивчення мовної картини світу об’єднує зусилля не тільки фахівців у галузі лінгвістики, етнопсихолінгвістики, когнітивного мовознавства, семантики, лексики, фразеології тощо, а й істориків, фольклористів, літературознавців, філософів. На точках перетину окреслених дисциплін утворено новітню наукову парадигму, що вможливлює різноаспектний підхід до опису, мотивацій та аналізу мовних явищ.

Мовна картина світу - інтерпретація довкілля, реальності, сприйняття й опис усього, що оточує людину. Однак таке зображення не є ані об'єктивним, ані універсальним; воно культурно зумовлене, адже передає погляди народу й безпосереднього конкретного індивіда. У центрі досліджень мовної картини світу — концепт. Концеепт з лат. concipere перекладають як “поняття”, однак розуміння концепту ширше, ніж поняття. Концептом уважають „інформаційну структуру, що відображає знання та досвід людини” [Кубрякова 1996: 90] (переклад автор. - 3. М. і М. Ф.), або ментальний прообраз (нерозчленоване уявлення про об'єкт), ідею та навіть саме поняття. Це ідеальний образ чи, 
точніше, прообраз, що уособлює культурно зумовлені уявлення мовця про світ. Водночас він передає певну ідентифікацію в мові, відповідно повинен досліджуватися в психічному та мовному аспектах. Одночасно упорядковане поєднання концептів у свідомості людини становить іï концептуальну систему, на формування якої одночасно впливає мовна картина світу. Концепт - це те, через що людина входить у культуру; етносвідомість; умовна ментальна структура, що має власне когнітивний статус та існує лише в мисленні. Комплексність концепту полягає в наявності двостороннього зв’ язку між мовою та свідомістю, оскільки категорії свідомості реалізовані в мовних категоріях; культура детермінує концепт як ментальну проекцію елементів культури. Співвідношення феноменів “мова” та “культура” складне, оскільки мова - одночасно й частина культури, і зовнішній для культури фактор; мова та мовлення - сфери, у яких концепт знаходить реальне (предметне) втілення. Складність розуміння вербалізації концепту простежуємо під час вивчення фразем (універсальних мовних категорій) з первинним компонентом, у яких спостережено нашарування його значеннєвих відтінків. У лінгвістиці підгрунтям концептуального аналізу мови та мовлення, дослідження фрагментів мовної картини світу українського народу стали праці С. Срмоленко, В. Жайворонка, В. Калашника, Ю. Карпенка, Л. Коломієць, Л. Лисиченко, Н. Сукаленко, О. Тищенко, В. Ужченка та ін. Також з'явилася низка досліджень, у яких розглянуто теоретичні питання етнолінгвістики (праці В. Іващенко В. Кононенка, Т. Космеди, Т. Радзієвської, нової та ін.).

Про концепт сьогодні пишуть дуже багато, однак i досі не існує однозначного його потрактування. Частина дослідників розуміє його „як універсальний центр, що формується у свідомості на базі безпосереднього чуттєвого досвіду, невимушених дій людини 3 предметами, а також на основі мовного спілкування та взаємодії 3 іншими уже сформованими концептами" [Кубрякова 2004: 4]. Інші вчені акцентують увагу на окремих моментах пояснення концептів, зокрема зауважуючи, що останні часто позначені етнокультурною специфікою (С. Воркачов); оточені емоційним, експресивним, оцінним ореолом (В. Колесов); розкривають культуру та ментальний світ людини через концепт (Ю. Степанов) тощо. Поділяючи погляд Й. Стерніна, розглядаємо концепт як дискретне ментальне утворення, що є базовою одиницею мисленнєвого коду людини [див.: Попова 2007: 34]. Спираючись на пояснення 3. Попової, концепт уважаємо відносно впорядкованою складною структурою, що $\epsilon$ результатом пізнавальної (когнітивної) діяльності особистості й суспільства та містить комплексну інформацію про предмет чи явище, інтерпретацію інформації суспільною свідомістю та відношення суспільної свідомості до безпосереднього явища чи предмета [Попова 2007: 314].

На нашу думку, концепт - це об’ єднання ментальних і психічних ресурсів нашої свідомості, тих поняттєво-інформаційних структур, що відображають 
знання та досвід людини. Науковці стверджують, що концепт як багатогранне й багатоаспектне культурно значуще соціопсихічне утворення в колективній свідомості певної мовної спільноти “розсіяний” у змісті лексичних одиниць, корпусі фразеології, пареміологічному фонді, системі стійких порівнянь, що відбивають образи-еталони [Longman 2000: 298], тобто концепт отримує мовне вираження через засоби мови, зокрема через фразеологічні одиниці. У сфері когнітивної парадигми фразеологізми розглядаємо як культурно зумовлену знакову репрезентацію інтеріоризованого етносвідомістю світу 3 притаманною їй категоризацією, субкатегоризацією, диференціацією й інтеграцією, як когнітивну форму оброблення інформації у свідомості людини [Кубрякова 2004].

Відомо, що матеріальне та духовне життя народу - це невичерпне джерело фразеотворення й водночас екстралінгвальна площина, на якій об' ємніше зображено й мовні цінності. Стійкі вислови, лаконічно й образно передаючи “великі мисленнєві маси”, створюють фразеологічну картину світу [Потебня 1993], що містить низку рівнів. Утілюючи різні аспекти народного буття, ці поля ілюструють вагомість вербалізованих ними подій, явищ, предметів. Фразеологія охоплює ті аспекти життєдіяльності народу, що в різних обставинах найважливіші для людини, і спрямовує фраземи на суб'єкт, тобто інтенція мовця-творця полягає не в намірі описати світ, а інтерпретувати його, оцінити. Структурні елементи концепту — це своєрідні концептуальні ознаки об'єктивного чи суб' єктивного світу, що відображені у свідомості та формують центр (основні поняття) та периферію (те, що вносить культура, традиції, досвід). В. Телія зазначає, що „взаємовідношення та взаємовплив одиниць фразеології й концептосфери культури постали зі здатності суб'єктів мови як суб'єктів культури втілювати в мовномисленнєвій діяльності знання, належні цій сфері усвідомлення світу людиною" [Телия 1999: 19] (переклад автор. - 3. М. і М. Ф.). Напевно, правомірно стверджувати, що концепт містить інтерпретаційне поле, яке розкривають саме фраземи. Адже фразеологізми через численні трактування, стереотипи й судження репрезентують цілісність концепту. Означені фразеологічні репрезентанти становлять периферію, що змінюється під впливом часу суспільних трансформацій і новацій. Щоб концепт був цілісним, варто простежувати його модифікації впродовж певного періоду. Ознаки концепту, реалізовані в численних (навіть суперечливих) висловах, зумовлені різними життєвими ситуаціями, обставинами та мотивацією, окреслюють узагальнений образ людини-мовця.

Отже, концепт як посередник між людиною та культурою постає перед нами у вигляді ментальних утворень, що виникають унаслідок взаємодії національної традиції та фольклору, релігії й ідеології, життєвого досвіду, мистецтва й системи цінностей. Як відомо, центром, згустком людського “Я” вважають душу. Саме тому мета цієї статті полягає в різновекторному си- 
нергетичному розгляді концепту “душа”, грунтованому на матеріалі ареальної фразеології як утілення споконвічної народної мудрості, єдності людини та всесвіту.

Найбільш складним і неоднозначним можна вважати саме концепт “душа”, що відбиває національно-культурну, ментально-психологічну специфіку й ціннісну орієнтацію українського народу. Акцентуємо на синергетичній інтерпретації філософського, мовного, буденного з погляду на означений суперконцепт, який окреслюємо як асоціативно-образний поліконденсат, що об’єднує макро-, мега-, мікросубконцепти й концепти, мовне актуалізування яких супроводжується взаємообумовленими й взаємозв'язаними процесами асоціювання, метафоризування, інтегрування, диференціювання, семантичної дифузії.

У Філософському енциклопедичному словнику поняття душа пояснено як „сукупність спонукань свідомості (і в той самий час основа) живої істоти, особливо людини; антитеза понять тіла й матерії; 3 наукової точки зору душа, на відміну від індивідуального духу, - сукупність тісно пов'язаних 3 організмом психічних явищ, зокрема почуттів і прагнень" [Философский энциклопедический словарь...: 179] (переклад автор. - 3. М. і М. Ф.). Довгий час тривали дискусії щодо того, чи є душа субстанцією. Давні уявлення про душу “як дихання” грунтовані на спостереженнях над диханням живої істоти, яка в “мертвого” зникала (тому що мертвий “видихав” душу): вidnycmuтu (одпустить) душу — 'померти'; випустити душу — 'померти' [Ужченко 2013: 196]; ду'ща з 'm'ілом розта йеu’'a — 'померти, потрапити в потойбіччя’ [Мацюк 2013: 81]; душа вилітає — '1) помирати; 2) хвилюватися'; віддати Богу душу — 'померти'; віддати дуиу — 'померти' [Доброльожа 2010: 66]. Філософське розуміння душі як субстанції зумовило те, що ії ототожнювали 3 властивостями “щонайтоншої речовини”. За Платоном, душа $\epsilon$ нематеріальною та передує існуванню. Аристотель називає ,iï першою ентелехією (цілеспрямованість як рушійна сила, активний початок) життєздатного тіла, тільки розумна душа людини може бути відокремлена від тіла і є безсмертною” [Философский энциклопедический словарь... 1997: 180] (переклад автор. - 3. М. і М. Ф.).

Сьогодні, як за часів античності та романтизму, часто знаходять відмінність між душею і свідомістю: душа - носій ритмічно плинних життєвих процесів, тоді як свідомість - на противагу душі - переривчаста. Усю історію цивілізації, історію розвитку людського знання, філософії, мистецтва можна розглядати з певних позицій як розвиток концепцій Людини й Душі.

Найбільш вагоме релігійне пояснення душі. Одні стверджують, що душа існує ще до народження. Душа — це ніби гармонія, що формується з тілесних начал. Душа безсмертна, вона продовжує існувати й має здатність мислити [Платон 1997: 92-93]. У більшості релігій світу уявлення про душу, що даро- 
вана Богом, про іiї безсмертя - основа священного віровчення. Тертулліан стверджував, що душа матеріальна, інші ж уважають їі духовною (Августин). Важливим у християнстві є розуміння душі як непросторової, нематеріальної субстанції.

Образно-смислову домінантність суперконцепту “душа” в українській національній самосвідомості простежуємо не тільки на поняттєвому, концептуально-онтологічному рівнях, а й на лексико-фразеологічному, що найбільш рельєфно репрезентовано в лексикографії. Адже, як генератор емоційного простору, мовну особистість інтерпретуємо як складну багаторівневу функційну систему, якій властиві рівні володіння мовою (мовна компетенція), володіння модусом реалізування мовної взаємодії (комунікативна компетенція), знання світу й про світ (когнітивно гносеологічний тезаурус). У кожному з ярусів знаходимо відображення народної мудрості, що має, відповідно, формальний, субстанціональний та інтенціональний рівні. У зв'язку із цим реалізування й актуалізування одиниць лінгвоконцептуальної дистрибуції суперконцепту “душа” (залежно від творця) характеризується неповторною самобутністю.

Як зазначено вище, доцільно в субконцепті “душа” виокремити центр периферію. Центральним уважаємо уявлення про душу як першопочаток життя та його кінець, тобто центр, грунтований на опозиції полярних понять життя - смерть (основних, найцінніших аспектів в існуванні людини у Всесвіті).

За народними віруваннями, душа 3'являється одночасно 3 народженням людини. Упродовж усього життя вона супроводжує людину, може покидати іiі тільки вві сні. На відміну від багатьох інших народів, українці вважали, що людина має одну душу, яку Бог дає їй при народженні. Мати дві душі, за народним віруванням, небезпечно. Дві душі може мати лише вагітна жінка, у ній “душа в душі”. У світовій і слов'янській міфології відбувається схрещення уявлень про душу як повітря, пару, хмаринку, вітер у міфополі фразеологізму душа вилітає з тіла. Або ж як образ птаха, що співвідноситься із зооморфними уявленнями про душу, яка готова полетіти. Найпоширеніша думка про те, що душа має вигляд бджоли, “божої мушки”, чи мухи з крилами, яких вона позбувається, увійшовши в тіло дитини. У вигляді мухи вона іноді навідується навіть до тієї хати, де очікують збільшення родини. У багатьох регіонах України існувало різне розуміння того, як душа приходить у тіло людини, напр.: удихнути душу — 'повернути до життя, придатності' [Доброльожа 2010: 67]. В одному випадку мати дає дитині й тілесне, і духовне життя (мати - берегиня душ); в іншому — душу дитині дає Бог, відряджаючи ангела віднести іiі майбутній людській істоті (антонімічний приклад душа до ангелів полетіла в кого - 'помер' [Ужченко 2013: 196]). У фразеології Західного Полісся фіксуємо одиниці безпосередньо народження: cхходит' йак 'Божа благофат'; 
з 'ірун'ка на 'неб 'і пуйавилас' “народження дитини' [Мацюк 2013: 301-302], де номени 'Божа благофат' та 'з'ірун'ка уособлюють душу дитини.

В українській фразеології закодовано міфологічні уявлення про душу, що безпосередньо пов'язані з уявленнями про потойбічне життя. Давні слов'яни вірили, що після смерті людина не припиняє свого життя (душа не покидає тіла людини), а тільки переходить до іншого світу. Однак пізніше, ще до поширення християнства, постало нове розуміння: „по смерті душа відділяється від тіла, яке гине, і живе окремим життям вічно, цебто душа безсмертна" [Іларіон 1992: 238]. Душа в уявленнях про потойбіччя інтерпретується через поняття “життя” і “смерті”. У фразеології зафіксовані вірування жителів та спрощене уявлення, згідно з яким людина має тільки душу й фізичне тіло. На думку вчених, ще раніше існувало вірування, ніби після смерті душа не розлучається з тілом, а зостається в ньому, тільки людина переходить до іншого світу. Після смерті душа повинна набути нових властивостей завдяки одній $з$ очисних стихій — вогню чи воді. Подібне уявлення засвідчують і Веди: душа померлого, покинувши тіло, піднімається до хмар, щоб небесним морем спуститися знов у підземне царство й там з'єднатися зі своїм тілом [Войтович 2002].

Наявність значної кількості фразеологічних одиниць із компонентом душа на позначення процесу смерті дослідники пов'язують з функціюванням табу, що вимагало евфемістичного опису цієї ситуації [Скаб 2008: 345]. Закінчення життя фразеологізми кодують через метафору розлуки тіла й душі: $\partial y ш а$ з 'm'ілом розтайеи'а [Мацюк 2013: 81]; ко'неи' йо'му вже, ду'ша од 'm'іла одле'т'іла 'померти, потрапити у потойбіччя'; заслужила ду'ща пуй'де до 'paйy, а не заслужила, то n'ildе в смо'лу [Мацюк 2013: 465]; преидставиелас' ууша 'Божа [Аркушин 2003: 6]; душа тіло оставыт - 'хто-небудь відчуває близьку смерть, умирає' [Ступінська 2012: 83], де процес смерті метафорично закодовано як виліт душі з тіла. Бінарні опозиції “морального” характеру накладають семантичний відбиток на світле й темне. Світлим і чистим $є$ Бог, а темним чорт. Смерть — це не тільки перехід в “інше” життя, це "інший”світ.

Метафоричне кодування у фразеологічних одиницях з компонентом душа внутрішнього світу людини (почуттів, емоцій) грунтовано на уподібненні психічних явищ до зовнішнього світу, природи, напр., порівняння з вогнем, водою, повітрям (ле́тит як без ду́шы — 'із страху, тривоги швидко біжить' [Вархол 1990: 54]). Уподібнення станів душі до стихії вогню інтерпретоване у фраземах: душа горить - 'хвилюватися'; душа кипить — 'обурюватися, бути невдоволеним'; душа пече - 'непокоїти' [Доброльожа 2010: 66]; кип 'яток за душею - 'сердитися'; пекти душу — 'образити когось' [Доброльожа 2010: 67] тощо. Метафоричне порівняння існування душі зі стихією води репрезентовано у фразеологізмах: душа пити просить - 'відчувати спрагу'; душа плаче - 'сумувати' [Доброльожа 2010: 66]; прийняти на душу п’ять 
капель - 'випити трохи спиртного' [Ужченко 2013: 197]; дy|ma nlpocum' polcoлу 'похмілля' [Мацюк 2013: 423], залиІла Ідушу й гочец̆ ни Івидно — 'зовнішні ознаки п’яної людини' [Мацюк 2013: 419], лити голій (жиру) за душу — 'завдавати неприємностей, болю' [Кірілкова 2013: 89]. Примітно, що фраземи кодують порівняння душі з природними стихіями: повітрям, вогнем, водою, однак практично не містять порівняння душі із землею. На наш погляд, це спричинене тим фактом, що земля в народній свідомості ототожнена 3 тілом людини й має матеріальний вияв. Землю, культ якої набагато давніший за культ Неба, шанували за те, що вона приймала у своє лоно душі померлих і повертала їх назад новонародженими. Помре людина - у тому місці душа йде в землю (душа у землю проситься — 'близький до смерті' [Ужченко 2013: 196]), а де народжується — звідти, із землі, душа повертається й переселяється в тіло новонародженого [Войтович 2002].

Лінгвосеміотичний і культурологічний рівні реконструкції експлікують ідеографічний “мовний образ душі” шляхом відтворення зовнішнього компаративного аспекту. На думку А. Вежбицької, концепт “душа", крім суто релігійного значення, має у своєму семантичному спектрі широку ідею внутрішнього життя людини, передусім iї емоційно-психічний бік [див.: Вежбицкая 2001: 95]. Зміни в психологічному й фізичному станах людини причина змінення місця локалізації іiі душі в тілі: одна душа в кармані, та й та хитається - 'про дуже бідну людину' [Чабаненко 2001: 99]; рада душа в рай, та гріхи не пускають — 'обмеження в чомусь' [Доброльожа 2010: 67]; пха́тисаякгрімна ду́mа до неба - 'напрошуватись кудись, де тебе не хочуть' [Вархол 1990: 54]; ду'ша не на 'м'іси'і / душа на 'мисие вирнулас' 'полегшення після якихось негараздів' [Мацюк 2013: 81].

Душа живої особистості присутня, живе й “мешкає” в тілі людини “усередині”, “у кожній частинці тіла”. Однак найчастіше душа локалізується в окремих частинах тіла, органа чи біля нього: у серці, п’ятах, грудях, животі, крові: душа в n'ятках опинилася - 'злякатися'; душа в n'ятки впала — 'злякатися' [Доброльожа 2010: 66]; душа в n'яти ховається — 'страшно'; душа в чоботах теленькає — 'страшно'; душа на павутиниі - 'лишилося недовго до смерті' [Чабаненко 2001: 40], ду'ша в 'пйатках; ду'ша в' пйатки; зл'а'калас'а, шо ду'ша в 'пйатках бу'ла — 'злякатися' [Мацюк 2013: 81]. Відомі також уявлення про переміщення душі в тілі. Іноді їй властиво покидати тіло від страху. В ареальних фразеологізмах простежуємо уявлення українців про душу як міс-

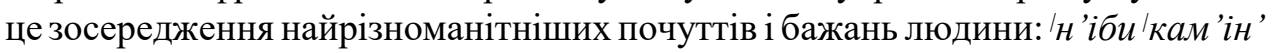

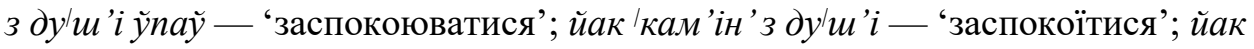
Ікам'ін'з ду ш'і ўпаў [Коваленко 2010]; камінюка з душі спала — 'стало легко, спокійно на душі'; ‘зникли якісь тривоги, турботи' [Чабаненко 2001: 69].

У сучасних лінгвокультурологічних концепціях людину вивчають як носія мови та носія культури одночасно. Саме тому мовні знаки отримують здат- 
ність виконувати функцію знаків культури, слугуючи засобом представлення основних настанов культури, що пояснює здатність мови відображати культурно-національну ментальність їі носіїв: лізти в душу — 'нахабна людина'; лізти з постолами в душу — 'нахабна людина'; наплювати в душу — 'образити когось'; не дати наплювати собі в душу — 'уміти постояти за себе' [Доброльожа 2010: 67].

Отже, проаналізувавши семантичну структуру ареальних фразеологічних одиниць, ми виявили в них національно-культурні компоненти, тобто ті мовні значення, що відображають, фіксують і передають від покоління до покоління особливості того чи того етносу (звичаї, вірування, морально-етичні оцінки, соціальні відносини, психічний і фізичний стан людини) - усе, що брало й бере участь у формуванні культурних кодів, визначає менталітет народу. Фразеологічні одиниці — це своєрідні мікросвіти, вони містять і моральний закон, і здоровий глузд, виражені в короткому вислові, що його заповідали предки для керівництва потомкам. В ареальних фразеологізмах відображено цілий спектр позитивних властивостей, якостей людини. Віковий досвід людей спонукав їх до витворення неповторної фразеологічної картини світу, що $\epsilon$ складником української ментальності.

Перспективними вбачаємо більш глибокі дослідження ареальної фразеологічної картини світу, створеної українським етносом.

\section{Список використаної літератури}

Аксянчук Г. Я., Чалавечая душа ў люстэрку рускай фразеалогіi, [в:] „Веснік Беларускага дзяржаўнага універсітэта. Серыя 4: Філалогія. Журналістыка. Педагогіка. Псіхалогія”, 1996, № 1, с. 33-37.

Аркушин Г., Сказав, як два зв'язав. Народні вислови та загадки із Західного Полісся $i$ західної частини Волині, Люблін-Луцьк: [б. в.], 2003.

Вархол Н., Івченко А., Фразеологічний словник лемківських говірок Східної Словаччини, Братислава: Словацьке пед. вид-во; Пряшів: Відділ укр. літ-ри, 1990.

Вежбицкая А., Понимание культур через посредство ключевых слов, Москва: Языки славянской культуры, 2001.

Войтович В. М., Українська міфологія, Київ: Либідь, 2002.

Гамзюк М., Особливості лексико-семантичних шляхів утворення фразеологічних одиниць, [в:] „Проблеми семантики слова, речення та тексту”, 2000, вип. 4, с. 37.

Доброльожа Г. М., Фразеологічний словник говірок Житомирщини, Житомир: ПП Туловський, 2010.

Іларіон Митрополит, Дохристиянські вірування украӥнського народу, Київ : АТ Обереги, 1992.

Кірілкова Н. В., Словник волинських фразеологізмів, Рівне; Острог: Вид-во Нац. ун-ту „Острозька академія”, 2013. 
Коваленко Н. Д., Слова з язика, як бджоли з вулика: матеріали до словника народних порівнянь подільських і волинських говірок Хмельниччини, Кам'янець-Подільський: ПП Буйницький, 2011.

Кубрякова Е. С., Кониепт. Конщептуализаџия, [в:] Краткий словарь когнитивных терминов, Москва: Филол. ф-т МГУ, 1996, с. 90-94.

Кубрякова Е. С., Об установках когнитивной лингвистики и актуальных проблемах когнитивной лингвистики, [в:] „Вопросы когнитивной лингвистики”, 2004, № 1, с. 6-17.

Мацюк 3., Із народу не викинеш: діалектний словник фразеологізмів, Луцьк: РВВ „Вежа” Волин. держ. ун-ту ім. Лесі Українки, 2006.

Мацюк 3., Що сільие, тонове слівие: словник фразеологізмів Західного Полісся, Луцьк: Вежа-Друк, 2013.

Пименова М. В., Коды культуры и проблема классификации конщептов, [в:] „Язык. Текст. Дискурс", 2007, вып. 5, с. 79-86.

Платон, О душе, [в:] П. Таранов, Мудрость трех тысячелетий, Москва: [б. и.], 1997, c. $92-93$.

Попова З. Д., Когнитивная лингвистика, Москва: АСТ; Восток-Запад, 2007.

Потебня А. А., Мыслль и язык, Київ: Синто, 1993.

Скаб М. В., Закономірності концептуалізації та мовної категоризації сакральної сфери, Чернівці: Рута, 2008.

Словник символів культури України, за заг. ред. В. П. Коцура та ін., Київ: Міленіум, 2002.

Смерчко А. А., Фразеологічні інновачіїяк результат мовотворчої діяльності людини, [в:] „Людина і творчість: гуманістичні вияви”, матер. людинознавчих філософ. читань, 1998, вип. VI, с. 203-210.

Ступінська Г.Ф., Битківська Я. В., Фразеологічний словниклемківськихговірок, Тернопіль: Навч. книга - Богдан, 2012.

Телия В. Н., Первоочередные задачи и методологические проблемы исследования фразеологического состава языка в контексте культур, [в:] Фразеология в контексте культуры, Москва: Языки рус. культуры, 1999, с. 13-24.

Телия В. Н., Русская фразеология. Семантический, прагматический и лингвокультурологический аспекты, Москва: Школа „Языки рус. литературы”, 1996.

Ужченко В. Д., Ужченко Д. В., Барвіна Н. О., Фразеологічно-паремійний словник Східної Слобожанщини XIX століття, Луганськ: Луган. нац. ун-т ім. Тараса Шевченка, 2013.

Философский энииклопедический словарь, гл. ред. Л. Ф. Ильичев, П. Н. Федосеев, С. М. Ковалев, В. Г. Панов, Москва: Сов. энциклопедия, 1983.

Чабаненко В., Фразеологічний словник говірок Нижньої Наддніпрянщини, Запоріжжя: [б. в.], 2001.

Чибор І., Слов'янська міфологія в українській фразеології, Київ: Видавець О. Філюк, 2016. Longman, Idioms Dictionary, Harlow: Pearson Education Limited, 2000.

\section{Spysok vykorystanoi literatury [References]}

Aksjanchuk G. Ja., Chalavechaja dusha w ljustjerku ruskaj frazealogii [A Human Soul in the Mirror of Russian Phraseology], [v:] „Vesnik Belaruskaga dzjarzhawnaga universitjeta. Seryja 4: Filalogija. Zhurnalistyka. Pedagogika. Psihalogija”, 1996, № 1, s. 33-37. 
Arkushyn H., Skazav, yak dva zviazav. Narodni vyslovy ta zahadky iz, Zakhidnoho Polissia $i$ zakhidnoi chastyny Volyni [Said How the Two Connected. Folk Expressions and Riddles from the Western Polesie and the Western Part of Volyn], Liublin-Lutsk: [b. v.], 2003.

Varkhol N., Ivchenko A., Frazeolohichnyi slovnyk lemkivskykh hovirok Skhidnoi Slovachchyny [Phraseological Dictionary of the Lemko Dialects of Eastern Slovakia], Bratislava: Slovatske ped. vyd-vo; Priashiv: Viddil ukr. lit-ry, 1990.

Vezhbytskaya A., Ponimanie kul'tur cherez posredstvo klyuchevyx slov [Understanding the Cultures via Instrumentality of Keywords], Moskva: Yazyki slavyanskoj kul'tury, 2001.

Voitovych V. M., Ukrainska mifolohiia [Ukrainian Mythology], Kyiv: Lybid, 2002.

Hamziuk M., Osoblyvosti leksyko-semantychnykh shliakhiv utvorennia frazeolohichnykh odynyts [The Features of Lexico-semantic Ways of the Formation of Phraseological Units], [v:] „Problemy semantyky slova, rechennia ta tekstu”, 2000, vyp. 4, s. 37.

Dobrolozha H. M., Frazeolohichnyi slovnyk hovirok Zhytomyrshchyny [Dictionary of Dialects of Zhytomyrshchyna], Zhytomyr: PP Tulovskyi, 2010.

Ilarion Mytropolyt, Dokhrystyianski viruvannia ukrainskoho narodu [Pre-Christian Beliefs of the Ukrainian People], Kyiv: AT „Oberehy”, 1992.

Kirilkova N. V., Slovnyk volynskykh frazeolohizmiv [Dictionary of Volyn Phraseologisms], Rivne; Ostroh: Vyd-vo Nats. un-tu „Ostroz. akad.”, 2013.

Kovalenko N. D., Slova z yazyka, yak bdzholy z vulyka: materialy do slovnyka narodnykh porivnian podilskykh i volynskykh hovirok Khmelnychchyny [Words out of Mouth as Bees out of Beehive: Materials to the Dictionary of Folk Comparisons of Podilsky and Volyn Dialects in Khmelnytsky Region], Kam'ianets-Podilskyi: PP Buinytskyi, 2001.

Kubryakova E. S., Koncept. Konceptualyzaciya [Concept. Conceptualization], [v:] Kratkij slovar' kognitivnyx terminov, Moskva: Fylol. f-t MHU, 1996, s. 90-94.

Kubryakova E. S., Ob ustanovkax kognytyvnoj lingvistiki $i$ aktualnyx problemax kognitivnoj lingvistiki [On the Installations of Cognitive Science and Actual Problems of Cognitive Linguistics], [v:] „Voprosy kognitivnoj lyngvistiki”, 2004, № 1, s. 6-17.

Matsiuk Z., Iz narodu ne vykynesh: dialektnyi slovnyk frazeolohizmiv [It Won t be Dropped out: Dialect Vocabulary of Phraseologisms], Lutsk: RVV „Vezha” Volyn. derzh. un-tu im. Lesi Ukrainky, 2006.

Matsiuk Z., Shcho siltse, to nove slivtse: slovnyk frazeolohizmiv Zakhidnoho Polissia [Words Differ in Different Villages: Phraseological Dictionary of Western Polissia], Lutsk: VezhaDruk, 2013.

Pimenova M. V., Kody kultury i problema klassifikacii konceptov [Cultural Codes and the Problem of Classification of Concepts], [v:] ,Yazyk. Tekst. Diskurs”, Stavropol: Izd-vo Pyatigor. gos. lingv. un-ta, 2007, vyp. 5, s. 79-86.

Platon, O dushe [About Soul], [v:] P.Taranov, Mudrost' trex tysyacheletij, Moskva: [b. i.], 1997, s. 92-93.

Popova Z. D., Kognitivnaya lyngvistika [Cognitive Linguistics], Moskva: AST; VostokZapad, 2007.

Potebnya A. A., Mysl' i yazyk [Thought and Language], Kyiv: Synto, 1993.

Skab M. V., Zakonomirnosti kontseptualizatsii ta movnoi katehoryzatsii sakralnoi sfery [Regularities of Conceptualization and Language Categorization of Sacral Sphere], Chernivtsi: Ruta, 2008. 
Slovnyk symvoliv kultury Ukrainy [Dictionary of the Symbols of Ukrainian Culture], za zah. red. V. P. Kotsura ta in., Kyiv: Milenium, 2002.

Smerchko A. A., Frazeolohichni innovatsii yak rezultat movotvorchoi diialnosti liudyny, [v:] „Liudyna i tvorchist: humanistychni vyiavy, mat. liudynoznavchykh filosof. chytan”, 1998, vyp. VI, s. 203-210.

Stupinska H. F., Bytkivska Ya. V., Frazeolohichnyi slovnyk lemkivskykh hovirok [Phraseologial Dictionary of the Lemko Dialects], Ternopil: Navch. knyha - Bohdan, 2012.

Teliya V. N., Pervoocherednye zadachi $i$ metodologicheskie problemy issledovaniya frazeologicheskogo sostava yazyka $v$ kontekste kul'tur [First Priority Tasks and Methodological Problems of the Research of Phraseological Language Composition in the Context of Cultures], [v:] Frazeologiya v kontekste kul'tury, Moskva: Yazyki rus. kul'tury, 1999, s. 13-24.

Teliya V. N., Russkaya frazeologiya. Semanticheskij, pragmaticheskij i lingvokul'turologicheskij aspekty [Russian Phraseology. Semantic, Pragmatic and Lingua Cultural Aspects], Moskva: Shkola „Yazyki rus. literatury”, 1996.

Uzhchenko V.D., Uzhchenko D. V., Barvina N. O., Frazeolohichno-paremiinyi slovnyk Skhidnoi Slobozhanshchyny XIX stolittia [Phraseologically-Variable Dictionary of Eastern Slobozhanshchina of the XIX Century], Luhansk: Luhan. nats. un-t im. Tarasa Shevchenka, 2013.

Filosofskij e'nciklopedicheskij slovar' [Philosophical Encyclopedic Dictionary], gl. red. L. F. Il'ichev, P. N. Fedoseev, S. M. Kovalev, V. G. Panov, Moskva: Sov. e'nciklopediya, 1983.

Chabanenko V., Frazeolohichnyi slovnyk hovirok Nyzhnoi Naddniprianshchyny [Phraseological Dictionary of the Dialects of Lower Dniper], Zaporizhzhia: [b. v.], 2001.

Chybor I., Slovianska mifolohiia v ukrainskii frazeolohii [Slavic Mythology in Ukrainian Phraseology], Kyiv: Vydavets Oleh Filiuk, 2016.

Longman, Idioms Dictionary, Harlow: Pearson Education Limited, 2000. 